\title{
THE ENVIRONMENTAL RESPONSIBILITY OF THE WORLD'S LARGEST BANKS
}

\author{
Bożena RYSZAWSKA ${ }^{1}$, Justyna ZABAWA ${ }^{2}$ \\ ${ }^{1,2}$ Wroctaw University of Economics, Wrockaw, Poland \\ Corresponding author e-mail: justyna.zabawa@ue.wroc.pl
}

\begin{abstract}
Sustainability transition is changing the role and function of banks, specially their products and services also in relation to stakeholders. Banks are one of the main actors supporting the transition to sustainable economy. The purpose of this study is to emphasise the role of world's largest banks in that process. Banks are slowly responding to the new demand of sustainability and responsibility, and they try to align with it. The paper is based on an overview of the world's five largest banks that employ corporate social responsibility (CSR) reporting standards, together with detailed enumeration of pro-environmental activities included in the reports. The first section of this paper presents the most popular approaches to the problem at hand, as reported in professional literature. Section two presents the characteristics of the CSR actions in banks. The third section discusses the environmental actions of the biggest banks in Global Reporting Initiative (GRI) reporting the most popular standard for reporting nonfinancial information. And the last part of the paper presents the conclusions resulting from the article. The research was conducted using a variety of sources, such as scientific articles, statistical data, CSR reports of the world's largest banks, as well reporting principles and standard disclosures. The basic method used in the process of writing was a critical analysis of literature and reports concerning the CSR reporting standards, environmental responsibilities of different kinds of entities, as well as own observations based on special reports of banks. In the article, also the analysis of financial market data, induction method and comparison method have been used. The main conclusions of the analysis of the CSR reports disclosed by the world's largest banks confirm all three of the theses presented in the article. The findings suggest that the banks under study can be regarded as environmentally responsible entities. Their reports and disclosures are produced according to the internationally recognized standards. There are also critical opinions about the standards for reporting environmental information, but the weaknesses of reporting these aspects do not undermine the benefits of using the GRI guidelines.
\end{abstract}

Keywords: Bank, corporate social responsibility (CSR), environmental responsibility, Global Reporting Initiative (GRI), sustainable development (SD).

JEL Classification: Q56, Q50, Q01, G21. 


\section{INTRODUCTION}

Sustainability transition is changing the role and function of banks, specially their products and services also in relation to stakeholders. Banks are one of the main actors supporting the transition to sustainable economy. The concept of sustainable development (SD) has become an important objective of policy makers on the government and business levels. It is due to an increased awareness and acceptance of sustainable practices by corporations and shift towards expanding corporate goals from growth and profitability to sustainability. The new trends in economy are already a fact. We can see sustainable banking, eco-taxes, green investment funds, green public procurement, eco-innovations in industry, low carbon economy, alternative sources of energy, etc. Banks will no longer be neutral intermediary organizations between companies and consumers. They are seen as active actors in the economic and social processes. Banks present their social and environmental responsibility by annual corporate social responsibility (CSR) reporting.

The most popular is Global Reporting Initiative (GRI). The GRI guidelines are presently the most popular standard for reporting non-financial information, designed by GRI, an international non-profit organisation. The GRI G4 constructs references and supports the international standards of CSR and sustained development reporting, such as the "OECD Guidelines for Multinational Enterprises", "the Ten UN Global Compact Principles", and the "UN Guiding Principles on Business and Human Rights". The GRI guidelines have evolved over the years, from GRI G1 up to the present G4 form. Work is under way to produce a definitive set of GRI Standards. However, for the time being, the GRI G4 guidelines remain the most popular reference set used by modern companies.

The purpose of this study is to emphasize the role of world's largest banks in the transition to sustainable economy.

As a consequence of socio-economic changes, banks should form specific benchmarks for other entities in the economies of modern countries. Banks, as institutions of public trust, are also a determinant in the areas related to CSR, with particular emphasis on pro-environmental activities. A significant role of banks for modern economics is also confirmed by the financial results for the sector. One example is the relation of banking sector assets to GDP, which in the EU countries ranges from $67 \%$ for Lithuania to $1561 \%$ for Luxembourg (NBP Report, 2016).

The first section of this paper presents the most popular approaches to the problem at hand, as reported in professional literature. Section two presents the characteristics of the CSR actions in banks. The third section discusses the environmental actions of biggest banks in GRI reporting. And the last part of the paper presents the conclusions resulting from the article.

\section{METHODS AND PROCEDURES}

The study is mostly of a theoretical character. The basic method used in the process of writing was a critical analysis of literature concerning the sustainable transition of economy and its impact on the greening of finance and banking. Also, 
critical analysis of banks' environmental reports, prepared according to GRI standards, as well as induction method and comparison method have been used. Then an attempt is undertaken to explain the environment-friendly behavior of banks. The empirical part using descriptive analysis illustrates the theoretical results with examples and data from the banks' reports. The study ends with conclusions.

The main theses can be expressed as follows:

Thesis 1: The environmental responsibility of the largest banks is, at present, very important, and the most internationally comparable effects obtained from the realization of the corporate social responsibility (CSR) idea. Environmental actions of banks have real impact on the reduction in natural resource, energy consumption and emission of $\mathrm{CO}_{2}$;

Thesis 2: The world's largest banks conduct effective pro-environmental policies on each of the three levels of corporate environmental responsibility: support activities (I), internal economy (II), and pro-environmental investment and environmental risk (III);

Thesis 3: GRI (Global Reporting Initiative) is the most popular standard of nonfinancial information reporting used by the world's largest banking institutions. It means that banks are obligated to disclose detailed information about their environmental performance not only in the context of reputation.

\section{SUSTAINABLE TRENDS IN ECONOMY, AND ENVIRONMENTAL RESPONSIBILITY OF BANKS - LITERTURE REVIEW}

The current model of economy has failed - says Tim Jackson in his book "Prosperity without growth". It has failed because was not able to protect the fragile ecological systems on which we depend for survival. It has failed, spectacularly, in its own terms, to provide economic stability and secure people's livelihoods (Jackson, 2009). Today's world is characterized by the degradation of forests, lakes and soils, conflicts over land use, water quality, fishing rights, and the concentrations of carbon in the global atmosphere. And we face these tasks with an economy that is fundamentally broken, in desperate need of renewal. In these circumstances, a return to business as usual is not an option.

Banks and financial institution have to face challenges connected with transition to green, low-carbon economy which means mainstreaming the environment into economic development. The theory of finance needs to incorporate the socio-ecologically embedded nature of finance (Fullwiler, 2015, p. 18). There are many initiatives which can be taken by banks, for example, saving energy, reducing waste, financing the sectors of clean production, eco-innovations and environmental investments (Atkisson, 2012). Green low-carbon economy designs new jobs, attracts investors and is supported by governments. Markets for eco-friendly products and services generate profits. Citizens express their positive attitude towards sustainable initiatives of banks and are willing to invest their money in green investment funds and in the shares of companies in green economy.

The economy is a sub-system of the environment. All of the inputs to the economy come from the environment, and all of the wastes produced by it return to the environment. As the economy grows, it requires more resources and discharges 
more wastes. Since we live on a finite planet with limited resources, it is not possible for the economy to grow forever. This incredible increase in economic activity has resulted in an equally incredible increase in the use of resources and energy. This is a next challenge for banks to support the reduction in energy and resource consumption (Dietz \& O’Neill, 2013).

Recent transformation of banks is adopting itself to the new trend of greening finance and banking. L. Dziawgo confirms it: financial market has been involved in supporting proecological transformation of the society and economy and, at the same time, it has been evolving slightly towards "greening" financial market (Dziawgo, 2014, p. 11).

Another challenge for banks is mitigation and adaptation of climate change. A historic agreement to combat climate change and unleash actions and investment towards a low carbon, resilient and sustainable future was agreed by 195 nations in Paris in 2015 (GCF Dispatch, 2015). There is a special role of financial institution to create a partnership with government, civil society and industry to finance the implementation of this agreement (Recommendation of the Task Force on Climaterelated Financial Disclosures, 2017).

Ziolo and others confirm: Many banks have recently implemented policies and procedures that address the environmental and sustainability impacts of their operations. The term "green banking" reflects this kind of approach in the banking sector, which requires a strong policy framework, transparency of implementation, adapting an environmental and social management system, and exercising leadership in sustainable finance (Ziolo et al., 2017).

Business entities gradually depart from the business as a usual model of operation, looking for new business models. In the new model, they get involved in the realisation of the concept of social and environmental responsibility, designed to reduce the negative impact of the sector upon the natural environment, and the society at large banks has to align with this trend (Bouma, Jeucken \& Klinkers, 2017). In the recent years, they increased interest in the concept of corporate social responsibility which is called now corporate sustainability with a broader scope of actions that better address the challenges of the sustainability transition. Banks will no longer be neutral intermediary organisations between companies and consumers (Jeucken, 2004). They are seen as active actors in the economic and social processes. So far, banks have considered themselves to be uninvolved and neutral to environmental risks created by industry. They do not themselves create risks, do not destroy the environment, do not create waste, do not use unethically cheap labor, do not create inequalities. Banks adopt a significant aspect of CSR (according to ISO 26000) and GRI 4 as a reporting tool. This has happened by a sufficient pressure of governments and consumers

$\mathrm{W}$. Visser proposes a new concept of the responsibility of banks, which is called CSR 2.0 or Corporate Sustainability and Responsibility. This new approach acknowledges that 'sustainability' (with roots in the environmental movement) and 'responsibility' (with roots in the social activist movement) are really the two main games in town (Visser, 2015). This is the adequate approach in the "Age of Responsibility", which is searching for a new, sustainable and responsible development. CSR 2.0 means moving away from philanthropic activities, 
sponsorship of events, integration meetings and building of the image of the company, and the moving towards creating a strategy for limiting the negative impact on the environment and the social environment towards investing in responsible projects, for example, "clean" technologies and energy-saving products.

The old role of banks destabilizes. Banks are slowly responding to the new demand in sustainable economy to align with it (Guez \& Zaouati, 2015). It may be observed that the traditional banks as an institution are changing towards banking as a service adjusted to innovation, decentralized and sustainable production and consumption. Some of the manifestations of this process include banks as an active player in financing the production of energy from renewable sources, waste recycling, reduction in greenhouse gas emission, modern products and technologies with improved energy efficiency, sustainable transportation, sustainable supply chains, sustainable consumption (Financing a European Economy, 2017).

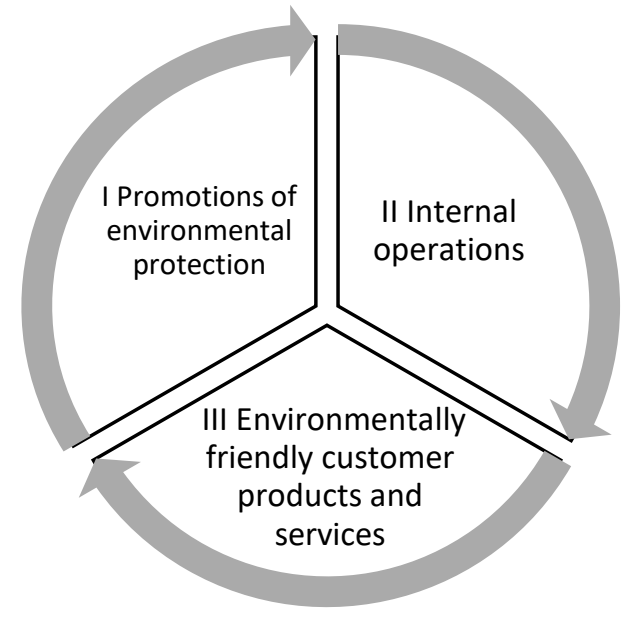

Fig. 1. Environmental operations of banks.

Source: authors' research based on Dziawgo L. (2010).

The environmental operations of banks can be sorted as (Fig. 1):

- active promotions of environmental protection, promoting ecological responsibility in the whole financial sector (dialogue with other institutions, sharing information with clients and other banks, supporting environmental R\&D and innovations);

- internal operations - consisting of the assessment of the consumption of energy and materials within the institution as well as the production of waste. Banks as an institution become responsible environmentally and reduce the burden on the environment. Specific bank projects can be related to energy saving, recycling and waste management and can create financial savings and reduce the costs of the bank;

- environmentally friendly customer products and services to identify and assess the risks of ecological projects (Schoenmaker, van Tilburg \& Wijffels, 2015) undertaken by bank. 
Remembering about the essential role of profit in the commercial activity of a bank, it is possible to differentiate between the further kinds of actions taken by banks within the scope of the protection of the environment in accordance with a certain hierarchy. Actions within the scope of voluntary sponsoring initiatives in the aid of the protection of the environment, as well as actions taken within the scope of marketing or public relations, may be regarded as the first, which means the lowest, level of the activity of a credit institution within the scope of the protection of the natural resources of environment. Actions conducted at this level require the smallest involvement for the part of a bank (Dziawgo \& Dziawgo, 2016).

Actions in the area of the internal economy of a bank the objective of which is such an organization of a workplace and the process of resource management which will take under consideration the requirements within the scope of the protection of the environment may be regarded as the second level of the involvement of a bank in the protection of the environment. Therefore, as part of these actions, it is so important to create an office organization friendly to the environment. Office materials, and also equipment, should not be harmful to the environment, and, moreover, it should be possible to recycle them. A significant role in shaping ecological culture may also be played by transport economy, for instance, by means of creating parking spaces for vehicles with catalytic converters. Moreover, within the scope of human resources management, it is possible to introduce an ecological incentive system which would reward suggestions put forward by employees and relevant to the ecologization of the working environment.

Actions aiming to protect the environment, in which a bank uses the specific character of the activity which it conducts, may be considered to be the highest level of the involvement of this institution for the protection of the environment. Here, it is possible to mention two groups of actions. The first of them includes financing typical ecological investments, such as, for instance, wind farms and waste-water treatment plants, whereas the second one includes financing the standard investments of economic subjects, which are based upon the solutions of ecological character. An instance of such an investment of an economic subject may be building a production room together with equipping it with devices producing thermal energy, which are, for instance, heat pumps. Moreover, as the actions at the third level, it is as well recognizing ecological risk in the process of financing economic investments that may be qualified.

Each of the following levels is a logical consequence of the previous ones. The full implementation on every level in a bank is possible due to the implementation of actions from previous levels. If the bank's activities are carried out only from selected levels, then it is not possible to speak about the full environmental responsibility of this financial institution.

Banking is the major channels of private financing for a sustainable economy. The financial services and investment sectors control trillions of dollars that could potentially be directed towards a sustainable economy. More importantly, banks are increasingly interested in acquiring portfolios that minimize environmental, social and governance risks, while capitalizing on emerging green technologies (UNEP, 2017). 


\section{ENVIRONMENTAL ACTIONS OF WORLD'S LARGEST BANKS IN CSR REPORTS - MAIN RESULTS}

The actions the objective of which is respecting environmental resources constitute the expression of fulfilling the idea of corporate social responsibility by contemporary organizations, and, therefore, by financial institutions such as, for instance, banks or insurance companies as well. Analysing the contemporary market of financial services, it is possible to observe that contemporary society, which is becoming more and more aware of the responsibility for the environment incumbent upon it, including as well that within the scope of the choice of a bank appropriate for it, makes such decisions which will not only turn out to be harmless but also friendly to the environment

Solutions and concepts raising the issue of the ecological dimension of the functioning of economic subjects in modern economy were already appearing in the 1980s in disciplines concerned with the functioning of enterprises. Currently, it is possible as well to observe that those actions within the scope of the ecological responsibility of contemporary societies are becoming one of the more important subjects raised in the mass media, debates in various milieus both in the countries of the European Union and those which have not yet joined this organization alike. The strategy "Europe 2020. A strategy for smart, sustainable and inclusive growth", developed by the European Commission in the year 2010, significantly determines the future of the ecological responsibility of contemporary credit institutions. Already the name of the document itself indicates that it is regulations in the area of the protection of the environment, and, therefore, applicable in the case of the world's biggest banks as well, will be treated as a priority.

Active involvement in pro-environmental activities can also be observed in the activities of banking institutions, including the world's largest banks. Table 1 presents a list of the world's largest banks (as per the end of 2015).

Table 1. The world's largest banks

\begin{tabular}{|c|l|c|c|}
\hline $\begin{array}{c}\text { Ranking } \\
\text { position }\end{array}$ & \multicolumn{1}{|c|}{ Bank } & Country & Assets (USD bn) \\
\hline 1 & Industrial \& Commercial Bank of China & China & 3420.57 \\
\hline 2 & China Construction Bank Corp. & China & 2826.04 \\
\hline 3 & Agricultural Bank of China & China & 2740.09 \\
\hline 4 & Bank of China & China & 2589.80 \\
\hline 5 & Mitsubishi UFJ & Japan & 2458.74 \\
\hline 6 & HSBC Holdings & Great Britain & 2409.66 \\
\hline 7 & JPMorgan Chase & USA & 2351.70 \\
\hline 8 & BNP Paribas & France & 2165.95 \\
\hline 9 & Bank of America & USA & 2144.32 \\
\hline 10 & Credit Agricole & France & 1845.18 \\
\hline
\end{tabular}

Source: Bratton \& Mehmood, 2016. 
Of note here is the fact that the four largest banks in the world have their origin in China. The dominant position of Asia is further enhanced by the recent advancement of the Japanese Mitsubishi UFJ Financial Group (The largest banks in the world, 2016). In addition, the sixth position in the above ranking is held by the HSBC Holdings registered in Great Britain, but with Asian roots. The practical impact of those institutions upon the global financial markets is undisputed. In this context, it might also be interesting to examine their impact upon the natural environment - both in terms of the scale of such influence and the range of methods employed for the purpose. The bulk of pro-environmental initiatives conducted by the largest banks is realised in the context of their CSR policies and included in their periodic CSR reports. Table 2 presents an overview of the world's five largest banks that employ CSR reporting standards, together with detailed enumeration of pro-environmental activities included in the reports. All of the institutions under examination conduct their business in Asia. In addition, Table 2 provides indications of standards employed in the preparation of reports, with proenvironmental activities mapped in accordance with the GRI G4 standard of internal environmental economy in banking.

Table 2. CSR reports by the world's largest banks

\begin{tabular}{|c|c|c|c|}
\hline No. & Bank & CSR Report & $\begin{array}{c}\text { Pro-environmental } \\
\text { activities }\end{array}$ \\
\hline 1 & $\begin{array}{l}\text { Industrial \& Commercial Bank of } \\
\text { China }\end{array}$ & $\stackrel{+}{+}$ & $\begin{array}{l}+ \\
+ \\
\text { G4-EN1 } \\
\text { G4-EN3 } \\
\text { G4-EN6 } \\
\text { G4-EN8 }\end{array}$ \\
\hline 2 & China Construction Bank Corp. & $\begin{array}{c}+^{1} \\
\text { GRI }\end{array}$ & N/A \\
\hline 3 & Agricultural Bank of China & $\stackrel{+}{+}$ & $\begin{array}{c}+ \\
\text { G4-EN3 } \\
\text { G4-EN4 } \\
\text { G4-EN6 } \\
\text { G4-EN7 } \\
\text { G4-EN11 } \\
\text { G4-EN12 } \\
\text { G4-EN19 } \\
\text { G4-EN27 } \\
\text { G4-EN31 } \\
\text { G4-EN32 } \\
\text { G4-EN33 }\end{array}$ \\
\hline 4 & Bank of China & + & + \\
\hline 5 & Mitsubishi UFJ & GRI G4 & $\begin{array}{l}\text { G4-EN3 } \\
\text { G4-EN5 } \\
\text { G4-EN6 } \\
\text { G4-EN7 } \\
\text { G4-EN8 } \\
\text { G4-EN11 } \\
\text { G4-EN12 } \\
\text { G4-EN13 } \\
\text { G4-EN15 }\end{array}$ \\
\hline
\end{tabular}




\begin{tabular}{|c|c|c|c|}
\hline No. & Bank & CSR Report & $\begin{array}{c}\text { Pro-environmental } \\
\text { activities }\end{array}$ \\
\hline & & & G4-EN16 \\
& & & G4-EN17 \\
& & & G4-EN18 \\
& & & G4-EN19 \\
& & & G4-EN22 \\
& & & G4-EN27 \\
\hline
\end{tabular}

${ }^{1}$ Reports are not available externally.

Source: authors' research based on CSR reports from the five largest banks in the world.

Pro-environmental activities presented in Table 2 according to GRI G4 Standard describe the disclosures (G4 Sustainability Reporting Guidelines) illustrated in Table 3.

Table 3. Pro-environmental disclosures in GRI G4

\begin{tabular}{|c|c|c|}
\hline Disclosure & Description & Aspect \\
\hline G4-EN1 & Materials used by weight or volume & Materials \\
\hline G4-EN3 & Energy consumption within the organization & Energy \\
\hline G4-EN4 & Energy consumption outside the organization & Energy \\
\hline G4-EN5 & Energy intensity & Energy \\
\hline G4-EN6 & Reduction in energy consumption & Energy \\
\hline G4-EN7 & $\begin{array}{l}\text { Reductions in energy requirements of products and } \\
\text { services }\end{array}$ & Energy \\
\hline G4-EN8 & Total water withdrawal by source & Water \\
\hline G4-EN11 & $\begin{array}{l}\text { Operational sites owned, leased, managed in, or } \\
\text { adjacent to, protected areas and the areas of high } \\
\text { biodiversity value outside protected areas }\end{array}$ & Biodiversity \\
\hline G4-EN12 & $\begin{array}{l}\text { Description of the significant impacts of activities, } \\
\text { products, and services on biodiversity in protected areas } \\
\text { and the areas of high biodiversity value outside } \\
\text { protected areas }\end{array}$ & Biodiversity \\
\hline G4-EN13 & Habitats protected or restored & Biodiversity \\
\hline G4-EN15 & Direct greenhouse gas (ghg) emissions (scope 1) & Emissions \\
\hline G4-EN16 & $\begin{array}{l}\text { Energy indirect greenhouse gas (ghg) emissions (scope } \\
\text { 2) }\end{array}$ & Emissions \\
\hline G4-EN17 & Other indirect greenhouse gas (ghg) emissions (scope 3) & Emissions \\
\hline G4-EN18 & Greenhouse gas (ghg) emissions intensity & Emissions \\
\hline G4-EN19 & Reduction in greenhouse gas (ghg) emissions & Emissions \\
\hline G4-EN22 & Total water discharge by quality and destination & $\begin{array}{l}\text { Effluents and } \\
\text { Waste }\end{array}$ \\
\hline G4-EN27 & $\begin{array}{l}\text { Extent of the impact mitigation of the environmental } \\
\text { impacts of products and services }\end{array}$ & $\begin{array}{l}\text { Products and } \\
\text { Services }\end{array}$ \\
\hline
\end{tabular}




\begin{tabular}{|c|c|c|}
\hline Disclosure & Description & Aspect \\
\hline G4-EN30 & $\begin{array}{l}\text { Significant environmental impacts of transporting } \\
\text { products and other goods and materials for the } \\
\text { organization's operations, and the transporting members } \\
\text { of the workforce }\end{array}$ & Transport \\
\hline G4-EN31 & $\begin{array}{l}\text { Total environmental protection expenditures and } \\
\text { investments by type }\end{array}$ & Overall \\
\hline G4-EN32 & $\begin{array}{l}\text { Percentage of new suppliers that were screened using } \\
\text { environmental criteria }\end{array}$ & $\begin{array}{l}\text { Supplier } \\
\text { Environmental } \\
\text { Assessment }\end{array}$ \\
\hline G4-EN33 & $\begin{array}{l}\text { Significant actual and potential negative environmental } \\
\text { impacts in the supply chain and actions taken }\end{array}$ & $\begin{array}{l}\text { Supplier } \\
\text { Environmental } \\
\text { Assessment }\end{array}$ \\
\hline
\end{tabular}

Source: G4 Sustainability Reporting Guidelines. Reporting Principles and Standard Disclosures, 2013.

Analysis show the diversity and multiplicity of environmental information released and disclosed by the largest modern banks. According to data in Tables 3 and 4, the main dimensions of the bank's environmental activity are: energy, emissions, and biodiversity. Other dimensions include: water, materials, effluents, waste, products and services, transport and supplier environmental assessment as well. Energy is connected with many areas, such as energy consumption within/outside the organization, intensity, reduction in consumption and reductions in the energy efficiency of products and services. In the context of reporting according to GRI standards, the emissions in banks can mean: direct and indirect greenhouse gas emissions, greenhouse gas emissions intensity, reduction in greenhouse gas emissions. Biodiversity describes: operational sites owned, leased, managed in, or adjacent to, protected areas and the areas of high biodiversity value outside protected areas; description of the significant impacts of activities, products, and services on biodiversity in protected areas and the areas of high biodiversity value outside protected areas and habitats protected or restored.

The presentation of harmonized environmental information by banks in accordance with GRI standards confirms the thesis that activities in this area show the most internationally comparable effects realized by the largest modern banks.

The GRI guidelines provide generic sets of disclosures used to communicate the environmental effects of business operation, together with detailed and up-todate disclosures on specific topics included in the subsequent sections of the report, related to specific CSR areas of the reporting entity's operation. The GRI-based reporting standard places strong emphasis on the role and significance of stakeholder relations in all the CSR areas. Stakeholders, in this approach, represent customers, suppliers, local communities, employees, and owners.

Table 4 presents the examples of pro-environmental activities undertaken by the reporting entities. In addition, the Table presents data on greenhouse gas emission reductions reported by the entities under study. The real reduction in the emissions and consumption of resources is in compliance with the implementation of low-carbon economy assumptions and global climate goals adopted at the conference in Paris in 2015 (United Nations Framework Convention on Climate Change, 21st Conference of the Parties, COP 21). The Paris UN Climate 
Conference represented a historic opportunity to put the world on course to meet the climate change challenge. The world needs a new model of growth that is safe, durable and beneficial to people from all countries (Figueros, 2015). COP21 tried to deliver a clear pathway with short and long-term milestones, first of all in environmental aspects.

Table 4. Examples of pro-environmental activities undertaken by the world's largest banks in 2015

\begin{tabular}{|c|c|c|c|}
\hline No. & Bank & Pro-environmental investments & Emission reduction \\
\hline 1 & $\begin{array}{l}\text { Industrial \& } \\
\text { Commercial Bank } \\
\text { of China }\end{array}$ & $\begin{array}{l}\text { A total of } 702843 \text { billion loans to } \\
\text { ecological protection, clean energy, } \\
\text { environmental protection, resource } \\
\text { recycling and other green economic } \\
\text { development projects. }\end{array}$ & $\begin{array}{l}\text { Dust }-12139 \text { tons } \\
\mathrm{CO}_{2}-44496 \text { tons } \\
\mathrm{SO} 2-1339 \text { tons } \\
\mathrm{NOX}-669 \text { tons }\end{array}$ \\
\hline 2 & $\begin{array}{l}\text { China Construction } \\
\text { Bank Corp. }\end{array}$ & - & - \\
\hline 3 & $\begin{array}{l}\text { Agricultural Bank of } \\
\text { China }\end{array}$ & $\begin{array}{l}\text { By the end of } 2015, \text { ABC's green } \\
\text { credit indicators having covered } 16 \\
\text { industries' credit policies, such as } \\
\text { cement, steel, petrifaction, mat glass, } \\
\text { wind power, photovoltaic, and so } \\
\text { forth, and involving } 4935 \text { customers, } \\
\text { the loan balance is } 543,13 \text { billion } \\
\text { yuan; the balance loans supporting } \\
\text { water pollution governance in ABC is } \\
1,32 \text { billion yuan, and the loan balance } \\
\text { for renewable and clean energy } \\
\text { projects is } 199.00 \text { billion yuan. }\end{array}$ & $\begin{array}{l}\text { The standard coal } \\
\text { emission reduced by } \\
6000 \text { tons, and } \\
\text { greenhouse gas } \\
\text { emission } \\
\text { reduced by } 18600 \\
\text { tons. }\end{array}$ \\
\hline 4 & Bank of China & $\begin{array}{l}\text { Green credits (RMB } 100 \text { million) - } \\
4123 \text {. } \\
\text { Loans to industries of high pollution, } \\
\text { high energy consumption - (RMB } 100 \\
\text { million) } 5118 \text {. } \\
\text { Credit line of RMB } 1 \text { billion for a } \\
\text { Public-Private-Partnership (PPP) } \\
\text { domestic garbage incineration for } \\
\text { power generation in Yinzhou District, } \\
\text { Ningbo. This is the first loan to PPP } \\
\text { projects in Ningbo, making positive } \\
\text { contribution to local environmental } \\
\text { and ecological construction. }\end{array}$ & $\begin{array}{l}\text { The bank actively } \\
\text { implemented the } \\
\text { Beijing Municipal } \\
\text { Commission of } \\
\text { Development and } \\
\text { Reform and hired a } \\
\text { party to check and } \\
\text { verify the carbon } \\
\text { emission in four office } \\
\text { buildings and submit } \\
\text { the carbon emission } \\
\text { verification report. } \\
\text { The bank purchased } \\
\text { corresponding carbon } \\
\text { emission verification } \\
\text { quota to try eliminate } \\
\text { the carbon emission } \\
\text { from its operations. }\end{array}$ \\
\hline 5 & Mitsubishi UFJ & $\begin{array}{l}\text { The Bank of Tokyo-Mitsubishi UFJ } \\
\text { arranged ¥35 billion in project } \\
\text { financing for a solar power generation } \\
\text { project in Hosoe, Miyazaki Prefecture. }\end{array}$ & $\begin{array}{l}\text { Total } \mathrm{CO}_{2} \text { reduction } \\
\text { of } 999000 \text { tons per } \\
\text { year } 2015 .\end{array}$ \\
\hline
\end{tabular}




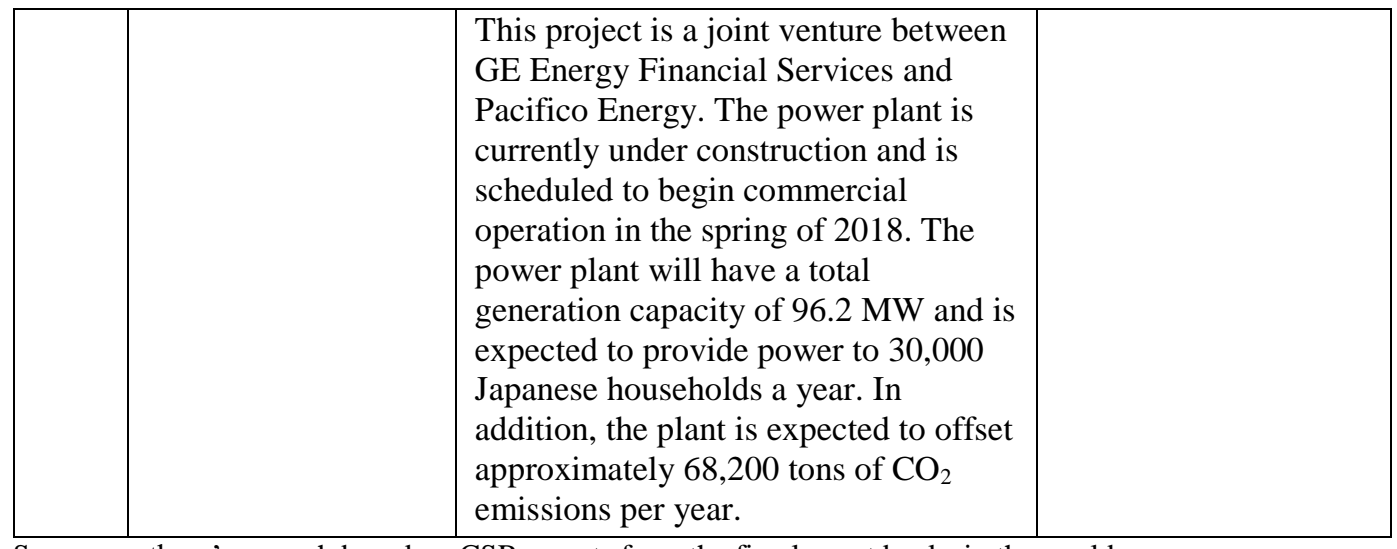

Source: authors' research based on CSR reports from the five largest banks in the world.

Environmental activities undertaken by the world's largest banks in 2015 were divided into two main groups: pro-environmental investments and emission reduction. According to data in Table 4, emissions are one of the main dimensions of the bank's environmental activity. In this dimension, the main meaning is held by the reduction of $\mathrm{CO}_{2}$. This is the main disclosure, which has a real influence on modern economy, on people and other companies in all the world. Industrial \& Commercial Bank of China confirms the reduction in the emission of $\mathrm{CO}_{2}$ in 2015 by 44.5 thousand tons, Agricultural Bank of China -6 thousand tons, and Mitsubishi UFJ - almost 1 million tons. Pro-environmental investments of the largest banks are connected first of all with credits and loans to environmental protection. Banks spend very large amounts of money on investments in: using of renewable energy sources (RES), and reducing air and water pollution. The largest bank - Industrial \& Commercial Bank of China - presents 702843 billion loans to ecological protection, clean energy and resource recycling as well. The Bank of Tokyo-Mitsubishi UFJ shows $¥ 35$ billion in project financing for a solar power generation project in Hosoe, Miyazaki Prefecture. For this reason, a growing interest in the investments in wind power, photovoltaic and solar panels in Asian countries has been observed recently.

\section{DISCUSSION AND CONCLUSION}

The analysis of the CSR reports disclosed by the world's largest banks seem to validate all three of the theses presented in the opening section. The findings suggest that the banks under study can be regarded as environmentally responsible entities. Their reports and disclosures are produced in accordance with the internationally recognised standards.

There are also critical opinions about the standards for reporting environmental information. Some companies are wasting time and money creating sustainability reports that are not effective (Leinaweaver, 2015). Other institutions that label themselves as GRI reporters do not behave in a responsible way concerning sustainability question, like: environmental protection, social equity or human rights. The concept of sustainable development (SD) that underlies the GRI guidelines for business to approach sustainability reveals some problems, e. g., 
promoting the construction of a set of indicators instead of instilling business with values to change their mentality so they can subscribe to the assumptions of SD (Moneva, Archel \& Correa, 2006).

However, it should be remembered that the weaknesses of reporting these aspects do not undermine the benefits of using the GRI guidelines.

Each of the analysed CSR reports was found to provide information in all three areas of environmentally responsible operation and environment protection. With the exception of the China Construction Bank Corp., all the entities made their disclosures public. The bank in question is known to produce their reports annually, but these disclosures are not available externally and as such cannot be subject to third-party analyses. The most detailed disclosures of internal banking policies in the studied context were produced by Mitsubishi UFJ. This bank, in accordance with the GRI standards, discloses the majority of indices covered by the GRI G4 guidelines for the evaluation of corporate pro-environmental involvement.

In the future, it is planned to continue research on a larger sample of financial institutions and in a longer time horizon as well. The proposition of further research concerns a group of banks, which will be increased also by institutions from the European Union and the Euro zone. The development of research fields related to pro-environmental activities and corporate social responsibility (CSR) is also the effect of the current EU law (Directive 2014/95/EU, 2014). The Directive concerns sharing non-financial information and information on diversity by some large entities and groups (directive 2014/95/EU - disclosure of non-financial and diversity information) and requires that the public interest entities, including banks, disclose information on, among other matters, their involvement in environment protection.

\section{REFERENCES}

Atkisson, A. (2012). Life Beyond Growth. Tokyo: ISHES.

Bouma, J.J, Jeucken, M. \& Klinkers, L. (2017). Sustainable Banking: The Greening of Finance, Routledge. $480 \mathrm{p}$.

Bratton, E. \& Mehmood, J.Z. (2016). Largest 100 Banks in The World. S\&P Global Market Intelligence Report. Retrieved from https://www.snl.com/InteractiveX/Article.aspx?cdid=A-36076706-13862

Dietz, R. \& O`Neill, D. (2013). Enough is Enough. Building a Sustainable Economy in World of Infinite Resources, London: Earthscan. 256 p.

Directive 2014/95/EU of the European Parliament and of the Council of 22 October 2014 amending Directive 2013/34/EU as regards disclosure of non-financial and diversity information by certain large undertakings. (2014). Retrieved from https://eur-lex.europa.eu/legalcontent/EN/TXT/?uri=CELEX:32014L0095

Dziawgo, L. (2010). Greening Financial Market. Eco-evolution of Financial Market, PWE.

Dziawgo, L. (2014). Greening Financial Market. Copernican Journal of Finance \& Accounting, 3(2), 9-23. https://doi.org/10.12775/CJFA.2014.014

Dziawgo, L. \& Dziawgo, E. (2016). Ecological Evolution of Financial Market: Ecologically Responsible Investment. In Bilgin M., Danis H., Demir E., Can U. (Eds.), Business Challenges in the Changing Economic Landscape - Vol. 1. Eurasian Studies in Business and Economics, 2(1), 167-178. https://doi.org/10.1007/978-3-319-22596-8 11

Financing a European Economy (2017). Interim Report, By the High-Level Expert Group on Sustainable Finance.

Fullwiler, S.T. (2015). Sustainable Finance: Building a More General Theory of Finance. Binzagr Institute for Sustainable Prosperity, Working Paper No. 106. 
G4 Sustainability Reporting Guidelines. Reporting Principles and Standard Disclosures. (2013). Global Reporting Initiatives. Retrieved from https://www.globalreporting.org/resourcelibrary/GRIG4-Part1Reporting-Principles-and-Standard-Disclosures.pdf

Guez, H. \& Zaouati, P. (2015). Positive Finance. A Toolkit for Responsible Transformation, Greenleaf Publishing. $128 \mathrm{p}$

Jackson, T. (2009). Prosperity without Growth. Economics for Finite Planet. London: Earthscan. 288 p.

Jeucken, M. (2004). Sustainability in Finance: Banking on the Planet, Eburon Uitgeverij B.V. 19-23.

Leinaweaver, J. (2015). Is Corporate Sustainability Reporting a Great Waste of Time? Retrieved December 15, 2017, from https://www.theguardian.com/sustainable-business/2015/jan/06/corporate-sustainabilityreporting-waste-time

Moneva, J.M., Archel, P.A., \& Correa, C.C. (2006). GRI and the Camouflaging of Corporate Unsustainability, Accounting Forum, 30, 121-137. https://doi.org/10.1016/j.accfor.2006.02.001

NBP Report 2016, Financial System in Poland.

Recommendation of the Task Force on Climate-related Financial Disclosures. (2017). Retrieved from https://www.fsb-tcfd.org/

Schoenmaker, D., van Tilburg, R., \& Wijffels, H. (2015). What Role for Financial Supervisors in Addressing Systemic Environmental Risks?, Sustainable Finance Lab Working Paper, Utrecht: Sustainable Finance Lab.

The largest banks in the world [Ranking]. (2016). Retrieved February 28, 2017, from http://www.bankier.pl/wiadomosc/Oto-najwieksze-banki-na-swiecie-Ranking-7359493.html

UNEP. (2017). On The Role Of Central Banks In Enhancing Green Finance, Inquiry Working Paper 17/01.

Visser, W. (2015). Sustainable Frontiers. Unlocking Change trough Business, Leadership and Innovation, Greenleaf Publishing. 245-253.

Zioło, M., Fidanoski F., Simeonovski K., Filipovski V. \& Jovanovska, K. (2017). Sustainable Finance Role in Creating Conditions for Sustainable Economic Growth and Development. In Leal Filho W. et al. (Eds.), Sustainable Economic Development, World Sustainability Series, Springer International Publishing Switzerland 2017. https://doi.org/10.1007/978-3-319-45081-0_11

Figueros, C. (2015). Paris Climate Change Conference - November 2015. United Nations Climate Change. Retrieved January 01, 2018, from http://unfccc.int/meetings/paris_nov_2015/meeting/8926.php.

GCF Dispatch. (2015). A Roundup of News from the Green Climate Fund Retrieved February 02, 2018, from http://www.greenclimate.fund/-/gcf-dispatch-december-2015-issue-5-

\section{AUTHORS' SHORT BIOGRAPHIES}

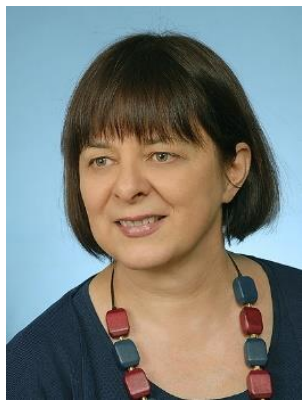

Bożena Ryszawska is an Associate Professor at the Corporate and Public Finance Department of the Wrocław University of Economics. Her research interests include green economy, sustainability transition, corporate sustainability, sustainable development, sustainable consumption, and public finance. She has 35 years of experience as a university Lecturer, and her teaching is focused on green economy, sustainable development, and public finance. B. Ryszawska received the Ph.D. in economics from the Wrocław University of Economics in 1990, and the habilitation degree - in 2015.

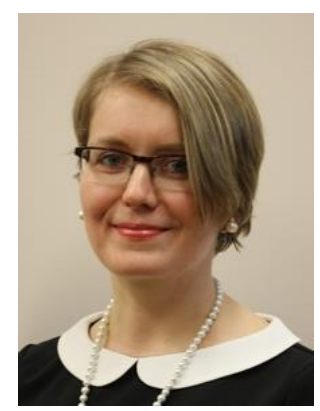

Justyna Zabawa received the Ph.D. degree in economics from the Wrocław University of Economics, Poland, in 2010. She has worked at the Department of Banking, Wrocław University of Economics, since 2010. Her research areas cover the topics of banking, green banking, corporate social responsibility (CSR) in finance, sustainable development, monetary policy. She has participated in many domestic and international research and business projects: Green Transfer, the Innovative Transfer, Pioneers into Practice (Climate KIC), Mechanisms of functioning of the euro area (Polish Central Bank), Green banking versus economic efficiency of Polish banking sector in the context of implementation of the Directive UE 2014/95/UE (National Science Centre, Poland). J. Zabawa is a Member of Sustainable Finance \& Accounting Association. 